\title{
PARTNERSHIP OF SCHOOL-FAMILY-COMMUNITIES AND ITS EFFECT ON STUDENT LEARNING OUTCOMES IN ELEMENTARY SCHOOL KEBUMEN
}

\section{Universitas Sebelas Maret suhartono@fkip.uns.ac.id}

Suhartono, Ngatman, Tri Saptuti Susiani, Ratna Hidayah

\section{Article History \\ accepted 30/09/2018 approved 12/10/2018 published 30/10/2018}

Keywords

School-family-community partnership, learning outcomes

\begin{abstract}
This study aims to find out the partnerships implementation among school, family, and communities and its effect on student learning outcomes in elementary school kebumen. This research includes quantitative descriptive research. The subjects in this study was consisted of five elementary schools. The research instruments were questionnaires and interview sheets. Data analysis was carried out using descriptive analysis with a quantitative approach. The results showed that: 1) the implementation of partnerships in elementary schools in Kebumen indicates a good category $(B)$ with a percentage of $82.50 \%$; 2) the partnerships of school-family-comunities in elementary schools have a significant influence on student learning outcomes.
\end{abstract}

Social, Humanities, and Education Studies (SHEs): Conference Series https://jurnal.uns.ac.id/shes 


\section{PENDAHULUAN}

Pendidikan di tingkat sekolah dasar (SD) menjadi pondasi pertama atau dasar pendidikan dalam upaya meningkatkan kualitas pendidikan di Indonesia. Hal ini dikarenakan SD adalah satuan pendidikan yang menyelenggarakan proses pendidikan dasar dan mendasari proses pendidikan selanjutnya dengan tujuan memberikan bekal kemampuan dasar membaca, menulis dan berhitung, pengetahuan dan keterampilan dasar yang bermanfaat bagi siswa sesuai dengan tingkat perkembangannya (Disdik.bekasikab.go.id). Selain memberikan bekal kemampuan dasar membaca, menulis, dan berhitung, pendidikan di sekolah dasar menjadi pondasi utama dalam pengembangan pendidikan karakter siswa.

Pengembangan karakter dan pendidikan karakter menjadi suatu keharusan karena pendidikan tidak hanya menjadikan siswa menjadi pandai dan cerdas, juga mempunyai budi pekerti dan sopan santun, sehingga keberadaannya sebagai anggota masyarakat menjadi bermakna baik bagi diri sendiri maupun orang lain. Pendidikan karakter yang paling mudah dilakukan di dunia pendidikan adalah ketika anak-anak masih di bangku SD. Oleh sebab itu, pemerintah selalu memprioritaskan pendidikan karakter di SD (Judiani, 2010). Salah satu usaha yang telah dilakukan oleh pemerintah dalam membangun dan mengembangkan pendidikan karakter di sekolah adalah dengan memasukkan muatan-muatan pendidikan karakter di kurikulum pendidikan. Sehingga tujuan sistem pendidikan nasional dapat dicapai dengan maksimal.

Berdasarkan Undang-Undang Dasar No 20 Tahun 2003 tentang Sistem Pendidikan Nasional dalam pasal 1 (1) disebutkan bahwa pendidikan adalah usaha sadar dan terencana untuk mewujudkan suasana belajar dan proses pembelajaran, agar anak didik secara aktif mengembangkan potensi dirinya, untuk memiliki kekuatan spiritual keagamaan, pengendalian diri, kepribadian, kecerdasan, akhlak mulia, serta keterampilan yang diperlukan dirinya, masyarakat, bangsa dan negara. Oleh sebab itu, pendidikan tidak hanya mencerdaskan anak didik, namun pembangunan dan pengembangan karakter anak didik menjadi hal yang harus diutamakan dalam dunia pendidikan.

Pengembangan pendidikan dalam rangka meningkatkan mutu kualitas pendidikan pada umumnya dan keberhasilan/prestasi siswa pada khususnya diperlukan kerjasama dari berbagai pihak yaitu satuan pendidikan (sekolah), keluarga, dan masyarakat. Namun, pada kenyataannya keberadaan partisipasi masyarakat dan bentuk partisipasi dalam lembaga pemerintahan dan lembaga-lembaga lainnya sampai kini masih menjadi perdebatan. Banyak warga negara dibatasi partisipasinya di masa silam bahkan sampai sekarang pun hal seperti ini masih kerap terjadi (Utari, 2010). Batasan-batasan yang terjadi antara satuan pendidikan, keluarga, dan masyarakat yang menjadi penghambat perlu dihilangkan dalam rangka meningkatkan keberhasilan peserta didik. Hal ini dikarenakan proses pendidikan terutama pendidikan di sekolah dasar akan berhasil bila keseluruhan ekosistem di sekeliling anak bergerak selaras.

Keselarasan pendidikan yang dilaksanakan satuan pendidikan dan di rumah diakui oleh para ahli pendidikan sebagai salah satu faktor penentu keberhasilan pendidikan anak secara menyeluruh (Kemdikbud, 2015). Belenardo (2001) menjelaskan bahwa upaya guru dan orang tua dalam mendidik anak sangat tergantung pada iklim dan budaya sekolah (Decker \& Decker, 2003). Epstein \& Voorhis (2010) menyatakan bahwa siswa akan belajar lebih manakala orang tua, pendidik, dan lainnya di masyarakat mengakui tujuan yang di-sharing-kan dan tanggung jawab terhadap belajar anak dan bekerjasama lebih baik daripada bekerja sendiri. Salah satu hal yang dapat dilakukan agar sekolah menjadi salah satu tempat yang aktif mengamalkan tugasnya adalah melalui suatu kemitraan atau kerjasama pendidikan dengan pihak luar sekolah.

Kemitraan yang diselenggarakan pada tingkat sekolah bertujuan untuk mewujudkan ekosistem pendidikan yang menumbuhkan karakter dan budaya prestasi 
semua warga sekolah khususnya siswa (Kemdikbud, 2015). Kemitraan antar pelaku pendidikan yang terdiri dari tiga unsur, yaitu keluarga, sekolah, dan masyarakat yang dalam hal ini diwakili oleh komite sekolah dapat digambarkan apabila setiap unsur dapat melaksanakan fungsi dan perannya secara baik. Oleh karena itu, manfaat dari kemitraan ketiga unsur tersebut harus mengarah pada siswa seperti yang terlihat pada gambar 1.

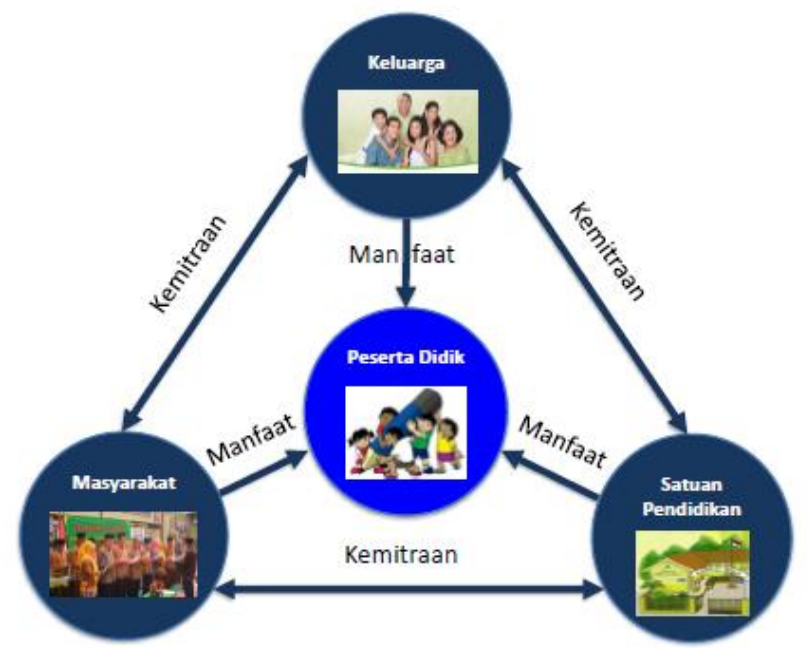

Gambar 1. Model Kemitraan Keluarga, Sekolah, dan Masayarakat (Sumber: Kemdikbud, 2015)

Beberapa penelitian tentang pentingnya kemitraan antara satuan pendidikan, keluarga, dan masyarakat bagi keberhasilan peserta didik adalah Sa'ad \& Sadiq tahun 2014 yang menghasilkan temuan bahwa kemitraan yang terjadi antara sekolah dan masyarakat sangat relevan dalam pembangungan pendidikan dasar di Kota Azare Nigeria karena masyarakat memiliki andil yang besar dalam menyediakan lahan untuk membangun sekolah, dana, fasilitas, mengawasi apa yang terjadi di sekolah, membangun ruang kelas tambahan dan membantu dalam pemeliharaan ketidakdisiplinan. Hasil penelitian dari World Bank (2013) menunjukkan bahwa intensitas dukungan keluarga berpengaruh meningkatkan pencapaian perkembangan anak usia dini di 50 kabupaten tertinggal. Penelitian Alves, dkk (2017) juga menghasilkan temuan bahwa lingkungan keluarga, sekolah, dan masyarakat memiliki dampak yang signifikan terhadap prestasi akademik anak. Penelitian oleh Nyatuka \& Nyakan (2015) menghasilkan temuan bahwa sepertiga dari guru SD dari Kenya yang ikut berpartisipasi tidak pernah mempelajari/mendapatkan materi atau mengikuti pelatihan yang terkait dengan kemitraan keluarga, sekolah, dan masyarakat. Pendidik perlu memahami tentang kemitraan antara sekolah, keluarga, dan masyarakat. Hal ini diyakini bahwa kemitraan memiliki pengaruh yang kuat pada perkembangan peserta didik baik secara akademis maupun perilaku. Boonk, dkk (2018) menganalisis beberapa kajian literatur tentang kemitraan orang tua dan sekolah terhadap prestasi belajar anak menghasilkan temuan bahwa keterlibatan orang tua terhadap prestasi belajar anak menunjukkan korelasi yang signifikan terhadap prestasi belajar anak. Berdasarkan penjelasan tersebut, dapat dirumuskan permasalahan sebagai berikut:

1. Bagaimana keterlaksanaan kemitraan keluarga, satuan pendidikan, dan masyarakat di sekolah dasar wilayah Kebumen?

2. Bagaimana pengaruh kemitraan keluarga, satuan pendidikan, dan masyarakat terhadap hasil belajar siswa di sekolah dasar wilayah Kebumen?

3. Apa saja hambatan dalam melaksanakan kemitraan keluarga, satuan pendidikan, dan masyarakat di sekolah dasar wilayah Kebumen? 


\section{METODE}

Penelitian ini merupakan penelitian deskriptif kuantitatif. Subjek dalam penelitian ini terdiri dari 5 sekolah dasar di wilayah Kebumen yang telah menerapkan kemitraan tri pusat pendidikan yaitu SD Negeri 06 Panjer, SD Negeri 01 Kebumen, SD Negeri 01 Kutosari, SD Negeri 02 Karangsari, dan SD Islam Ulil Albab yang melibatkan kepala sekolah, guru, siswa, dan komite sekolah. Penyusunan dan pengembangan alat pengumpulan data terdiri dari lembar angket untuk mengukur keterlaksanaan kemitraan di sekolah dan angket untuk mengukur hasil belajar siswa serta lembar wawancara untuk mengetahui informasi hambatan-hambatan yang di sekolah dalam melaksanakan kemitraan tri pusat pendidikan. Analisis data penelitian dilakukan menggunakan analisis deskriptif dengan pendekatan kuantitatif. Untuk mencari besar persentase keterlaksanaan kemitraan menggunakan persamaan 1.

$$
\text { Persentase keterlaksanaan }(p)=\frac{\text { skor hasil penelitian }}{\text { skor tertinggi ideal }} \times 100 \%
$$

Persentase keterlaksanaan tersebut dijadikan sebagai hasil untuk menentukan kriteria seperti yang terlihat pada Tabel 1.

\section{Tabel 1. Kriteria Keterlaksanaan Kemitraan Berdasarkan Nilai Persentase

\begin{tabular}{cc}
\hline Rentang Skor (\%) & Kategori \\
\hline $25-50$ & Kurang \\
$51-75$ & Sedang \\
$76-100$ & Baik \\
\hline
\end{tabular}

(Sumber: Arikunto, 2009)

Teknik pengolahan data untuk mengetahui pengaruh kemitraan terhadap hasil belajar menggunakan korelasi regresi. Korelasi regresi menggunakan bantuan SPSS dengan ketentuan jika $p$-value kurang dari 0,05 maka hipotesis nol ditolak. Artinya ada pengaruh kemitraan keluarga, satuan pendidikan, dan masyarakat terhadap hasil belajar siswa di sekolah dasar wilayah Kebumen.

\section{HASIL DAN PEMBAHASAN}

Kemitraan antara keluarga-satuan pendidikan-masyarakat di Sekolah Dasar (SD) wilayah Kebumen, Jawa Tengah dilaksanakan oleh 5 SD, yaitu SD Islam Ulil Albab, SD Negeri 6 Panjer, SD Negeri 2 Karangsari, SD Negeri 1 Kutosari, dan SD Negeri 1 Kebumen. Tabel 2 adalah hasil analisis keterlaksanaan kemitraan di SD wilayah Kebumen.

Tabel 2. Ringkasan Hasil Keterlaksanaan Kemitraan di SD Wilayah Kebumen

\begin{tabular}{cccc}
\hline Nama Sekolah & Rerata Skor & $\begin{array}{c}\text { Persentase } \\
\text { Keterlaksaan }\end{array}$ & Kriteria \\
\hline SD X1 & 0,73 & $73,69 \%$ & Cukup \\
SD X2 & 0,84 & $83,69 \%$ & Baik \\
SD X3 & 0,79 & $80,08 \%$ & Baik \\
SD X4 & 0,89 & $89,73 \%$ & Baik \\
SD X5 & 0,85 & $85,30 \%$ & Baik \\
Rata-Rata & $\mathbf{0 , 8 2}$ & $\mathbf{8 2 , 5 0 \%}$ & Baik \\
\hline
\end{tabular}

Tabel 2 menunjukkan bahwa keterlaksanaan kemitraan di SD wilayah Kebumen menunjukkan kriteria Baik dengan persentase sebesar 82,50\%. Keterlaksanaan kemitraan keluarga, sekolah, dan masyarakat yang baik mampu membangun ekosistem pendidikan yang kondusif dalam rangka mengembangkan potensi, karakter, 
dan budaya berprestasi peserta didik. Seperti yang dilakukan oleh SD X4 dengan nilai keterlaksanaan kemitraan paling tinggi dibandingkan sekolah yang lain. Dengan melihat hasil analisis, keterlibatan antara keluarga, masyarakat, dan sekolah di SD X4 sangat baik. Seperti keterlibatan orang tua/wali di sekolah tersebut menunjukkan $100 \%$ dalam mengikuti kegiatan/program dari sekolah.

Beberapa program dari sekolah dalam rangka penguatan kemitraan di SD adalah orang tua mengantar anak pada hari pertama masuk, orang tua datang pada pertemuan dengan pihak sekolah pada hari pertama masuk (orientasi wali murid dengan pihak sekolah), orang tua datang dalam program parenting di sekolah, orang tua menghadiri pentas yang dilakukan anak pada akhir tahun ajaran, orang tua berpartisipasi dalam peringatan hari keluarga nasional di sekolah, orang tua membentuk paguyuban orang tua antar kelas, orang tua memanfaatkan buku-buku perpustakaan yang ada di sekolah. Program-program tersebut menjadi indikator dalam rangka menguatkan kemitraan antara keluarga dan sekolah. Selain SD X4, SD yang lain menunjukkan kurang maksimalnya peran orang tua dalam kegiatan di sekolah. Khususnya pada kegiatan peringatan hari keluarga nasional dan pemanfaatan buku di perpustakaan. Kegiatan-kegiatan tersebut menjadi kegiatan yang paling banyak diabaikan oleh para orang tua/wali.

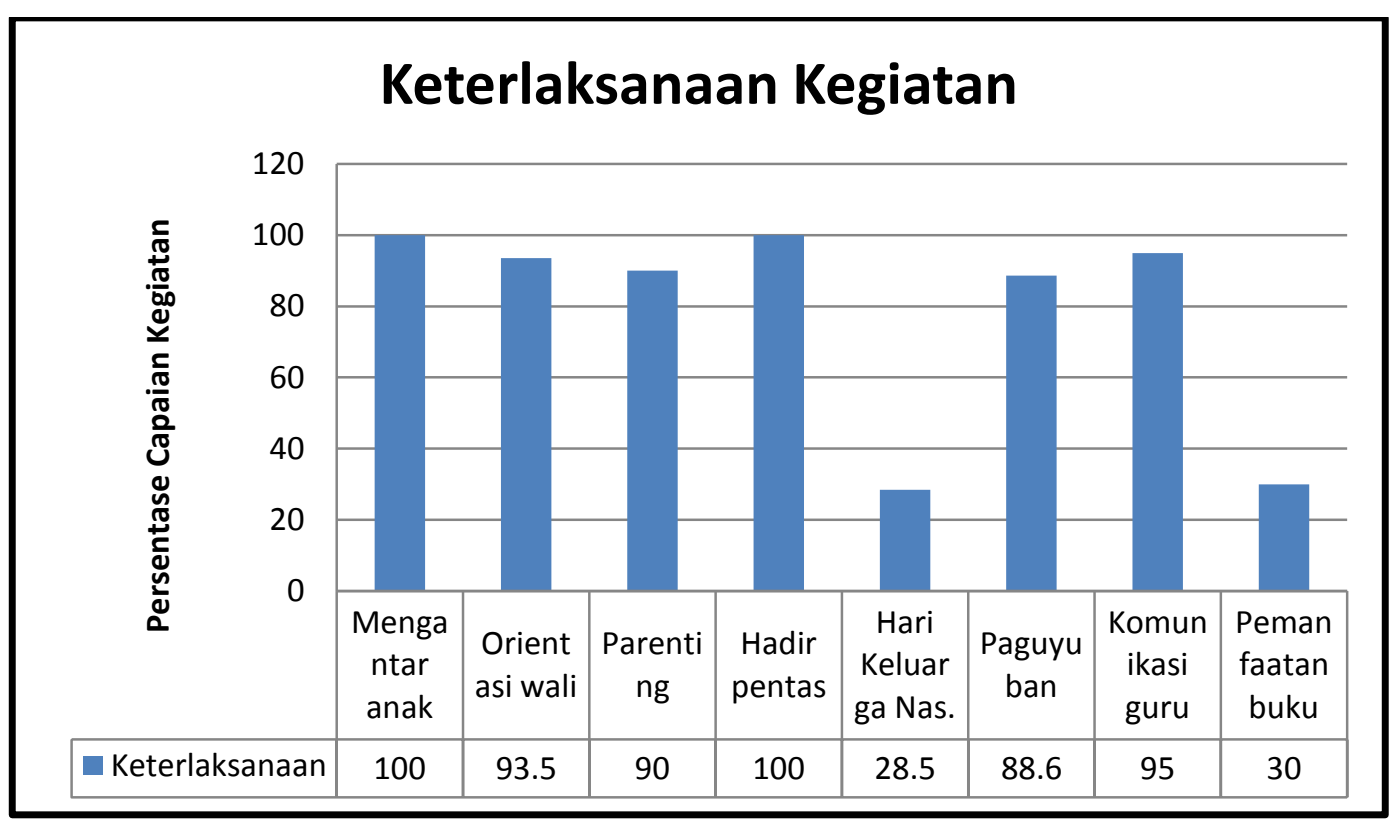

\section{Gambar 2. Keterlaksanaan Kegiatan Orang Tua/Wali}

Gambar 2 menunjukkan bahwa kegiatan orang tua dalam rangka penguatan kemitraan di sekolah paling rendah ditunjukkan pada kegiatan peringatan hari keluarga nasional dan kegiatan memanfaatkan buku di perpustakaan. Kurangnya partisipasi orang tua terhadap kegiatan hari keluarga nasional dikarenakan 4 dari 5 sekolah tidak menyelenggarakan kegiatan tersebut.

Keluarga memiliki peran yang sangat penting dalam perkembangan anak. Pada masa sekolah dasar awal keterikatan anak dengan orang tua masih kuat. Interaksi anak dengan orang tua/pengasuh serta kondisi lingkungan rumah memberikan pengaruh menetap dan jangka panjang pada kematangan perkembangan dan kesuksesan pendidikan anak. Dalam lingkungan keluarga, anak lebih mempunyai banyak kesempatan dalam membentuk kreativitas, tingkah laku/karakter, dan pengetahuan. Oleh sebab itu, pendidikan yang paling pertama dan utama terletak pada 
keluarga. Widianto (2015) mengemukakan bahwa orang tua di dalam keluarga memegang peranan penting untuk mengembangkan potensi anak dan meningkatkan pendidikan karakter anak. Ningrum (2016) menghasilkan temuan tentang peran orang tua dan pola pengasuhan berpengaruh secara signifikan terhadap prestasi belajar anak. Dijelaskan bahwa orang tua memegang peranan yang sangat penting dalam membimbing, mendampingi, dan menciptakan lingkungan yang knodusif sehingga dapat mengembangkan potensi anak, kecerdasan, dan rasa percaya diri. Selain itu, orang tua perlu memahami setiap tahap perkembangan anak serta kebutuhan pengembangan kecerdasan anak pada setiap tahap.

Selain lingkungan keluarga, lingkungan sekolah dan masyarakat memiliki peran masing-masing yang penting dalam proses pengembangan protensi anak. Sekolah dan masyarakat menjadi lingkungan selajutnya bagi anak dalam mengeksplor diri setelah mendapatkan pendidikan dalam keluarga. Pendidikan yang baik di lingkungan keluarga, sekolah, dan masyarakat mampu membentuk perkembangan dan kesuksesan pendidikan anak sehingga keselarasan pendidikan di lingkungan keluarga, sekolah, dan masyarakat menjadi salah satu faktor penentu keberhasilan pendidikan anak secara menyeluruh (Kemdikbud, 2015).

Peran sekolah dalam upaya penguatan kemitraan adalah dengan menciptakan ekosistem pendidikan yang aman, nyaman, ramah, dan sehat yang dapat menumbuhkan karakter dan budaya prestasi peserta didik melalui Manajemen Berbasis Sekolah (MBS). Usman (2014) menyebutkan MBS dapat didefinisikan dan penyerasian sumber daya yang dilakukan secara mandiri oleh sekolah dengan melibatkan semua kelompok kepentingan yang terkait dengan sekolah secara langsung dalam proses pengambilan keputusan untuk memenuhi kebutuhan mutu sekolah atau untuk mencapai tujuan mutu sekolah dalam pendidikan nasional. Esensi dari MBS ini adalah otonomi dan pengambilan keputusan partisipasi untuk mencapai sasaran mutu sekolah yang bertujuan untuk memandirikan atau memberdayakan sekolah melalui pemberian kewenangan, keluwesan, dan sumber daya untuk meningkatkan mutu sekolah.

Berdasarkan hasil analisis SD X5 paling tinggi dalam menerapkan kegiatankegiatan sekolah. Kegiatan-kegiatan yang bertujuan untuk menguatkan kemitraan di sekolah antara lain penumbuhan budi pekerti dan jiwa nasionalisme dengan cara berdoa sebelum dan setelah aktivitas pembelajaran, pembiasaan beribadah bersama, memperingati hari-hari besar keagamaan, memberikan salam senyum dan sapa pada warga di sekolah, membuang sampah pada tempatnya, membiasakan antre, melakukan upacara setiap hari senin dan hari besar nasional, menyanyikan lagu wajib dan daerah, serta menjaga kebersihan sekolah. Selanjutnya, budaya literasi dan bersikap kritis diharapkan dapat terwujud dengan adanya kegiatan membaca minimal 15 menit sebelum pembelajaran, membiasakan budaya bertanya dan bersikap kritis. Kegiatan literasi dan menyanyikan lagu wajib dan daerah menjadi kegiatan yang kurang ditekankan di sekolah. Sebesar $71,42 \%$ sekolah belum memaksimalkan budaya literasi, $100 \%$ peserta didik tidak diarahkan untuk menyanyikan lagu wajib atau membaca puisi perjuangan, dan sebesar $96 \%$ peserta didik tidak diarahkan untuk menyanyikan lagu daerah.

Kegiatan masyarakat dalam hal ini adalah komite sekolah juga merupakan salah satu upaya dalam peningkatan mutu pelayanan di sekolah. Kegiatan di tingkat komite sekolah dalam rangka menguatkan kemitraan adalah dengan adanya kegiatan pertemuan internal komite sekolah, kegiatan rapat pembahasan rencana kerja sekolah, dan kegiatan acara-acara besar di sekolah. Ketercapaian kegiatan masyarakat/partisipasi masyarakat di sekolah telah menunjukkan kategori baik dengan persentase keterlaksanaan kegiatan secara menyeluruh di SD wilayah Kebumen sebesar $0,83 \%$. Hal ini membuktikan bahwa masyarakat memiliki kepedulian yang baik terhadap perkembangan sekolah khususnya dalam hal peningkatan kualitas 
pendidikan. Hermawan \& Suryono (2016) mengemukakan bahwa masyarakat memiliki peran utama yang tidak bisa dilalaikan dalam upaya meningkatkan keberhasilan pendidikan. Kowalski (2004: 41) menyebutkan pentingnya sekolah menjalin kemitraan dengan masyarakat yaitu: masyarakat telah membayar pajak untuk terselenggaranya pendidikan; kebanyakan komunikasi sekolah dan masyarakat dilakukan satu arah, sehingga ada informasi dari masyarakat yang tidak sampai ke sekolah; pendekatn informal cenderung kurang efektif dibandingkan dengan cara yang lebih sistematis; dan masyarakat terdiri atas keberagaman.

Program penguatan kemitraan antara keluarga, satuan pendidikan, dan masyarakat menjadi salah satu kunci keberhasilan pendidikan anak-anak dalam upaya meningkatkan kualitas pendidikan. Korelasi antara kemitraan tripusat pendidikan terhadap hasil belajar siswa menunjukkan korelasi yang tinggi.

Tabel 3. Pengaruh Partial Kemitraan Keluarga, Sekolah, dan Masyarakat Terhadap Hasil Belajar

\section{Coefficients $^{\mathrm{a}}$}

\begin{tabular}{|c|c|c|c|c|c|c|}
\hline \multirow{2}{*}{\multicolumn{2}{|c|}{ Model }} & \multicolumn{2}{|c|}{$\begin{array}{l}\text { Unstandardized } \\
\text { Coefficients }\end{array}$} & \multirow{2}{*}{$\begin{array}{c}\text { Standardized } \\
\text { Coefficients } \\
\text { Beta }\end{array}$} & \multirow[b]{2}{*}{$t$} & \multirow[b]{2}{*}{ Sig. } \\
\hline & & $\mathrm{B}$ & Std. Error & & & \\
\hline \multirow[t]{4}{*}{1} & (Constant) & .761 & 1.218 & & .625 & .536 \\
\hline & kemitraansekolah & 1.806 & .230 & 1.675 & 7.868 & .000 \\
\hline & kemitraankeluarga & -.337 & .156 & -.340 & -2.161 & .038 \\
\hline & $\begin{array}{l}\text { kemitraanmasyara } \\
\text { kat }\end{array}$ & -.518 & .250 & -.482 & -2.073 & .046 \\
\hline
\end{tabular}

a. Dependent Variable: hasil belajar

Berdasarkan tabel 3 kemitraan keluarga, sekolah, dan masyarakat memiliki pengaruh yang signikan terhadap hasil belajar siswa dengan ditunjukkan oleh nilai Beta 0,498. Dengan demikian persamaan regresi temuan di atas adalah $\mathrm{Y}=$ $0,761+1,806 \mathrm{X}_{1}-0,337 \mathrm{X}_{2}-0,518 \mathrm{X}_{3}$.

Tabel 4. Ringkasan Hasil Anova Pengaruh Kemitraan Terhadap Hasil Belajar

\begin{tabular}{|c|c|c|c|c|c|c|}
\hline \multicolumn{7}{|c|}{ ANOVA $^{b}$} \\
\hline \multicolumn{2}{|c|}{ Model } & $\begin{array}{l}\text { Sum of } \\
\text { Squares }\end{array}$ & $\mathrm{df}$ & Mean Square & $F$ & Sig. \\
\hline \multirow[t]{3}{*}{1} & Regression & 84.958 & 3 & 28.319 & 82.485 & $.000^{\mathrm{a}}$ \\
\hline & Residual & 12.016 & 35 & .343 & & \\
\hline & Total & 96.974 & 38 & & & \\
\hline
\end{tabular}

a. Predictors: (Constant), kemitraanmasyarakat, kemitraankeluarga, kemitraansekolah

b. Dependent Variable: hasil belajar

Tabel 4 menunjukkan bahwa pengaruh simultan yang signifikan antara kemitraan keluarga, sekolah, dan masyarakat terhadap hasil belajar siswa dengan tingkat signikansi $0,000<0,05$. Artinya, kemitraan kelurga, sekolah, dan masyarakat bersama-sama memiliki pengaruh yang signifikan terhadap hasil belajar siswa. 


\section{Tabel 5. Kontribusi Kemitraan Keluarga, Sekolah, dan Masyarakat Secara Simultan Terhadap hasil belajar siswa Model Summary}

\begin{tabular}{llrrr} 
Model & $\mathrm{R}$ & R Square & $\begin{array}{c}\text { Adjusted R } \\
\text { Square }\end{array}$ & $\begin{array}{l}\text { Std. Error of } \\
\text { the Estimate }\end{array}$ \\
\hline 1 & $.936^{\mathrm{a}}$ & .876 & .865 & .58594 \\
\hline
\end{tabular}

a. Predictors: (Constant), kemitraanmasyarakat, kemitraankeluarga, kemitraansekolah

Tabel 5 menunjukkan bahwa koefisien Determinasi (KD) secara simultan menunjukkan nilai $R^{2} \quad 0,876$, artinya kemitraan keluarga, sekolah, dan masyarakat memberikan kontribusi sebesar $87,60 \%$ terhadap hasil belajar siswa, sedangkan sebesar $12,40 \%$ hasil belajar siswa dipengaruhi oleh variabel-variabel lain yang tidak diteliti dalam penelitian ini.

Kemitraan antara keluarga, sekolah, dan masyarakat berpengaruh terhadap peningkatan hasil belajar peserta didik. Adanya kerjasama antara pihak keluarga dan sekolah serta masyarakat mampu membangun ekosistem pendidikan yang kondusif dalam menumbuhkembangkan karakter dan budaya berprestasi peserta didik (Kemdikbud, 2015). Khususnya peran di lingkungan keluarga harus selalu dimonitoring karena pada masa sekolah dasar, anak masih memiliki keterikatan yang kuat dengan orang tua. Interaksi anak dengan orang tua memberikan pengaruh menetap dan jangka panjang pada kematangan perkembangan dan kesuksesan pendidikan anak.

Keterlaksanaan kemitraan akan lebih efektif jika keluarga, sekolah, dan masyarakat sebagai pemangku kepentingan menyadari akan peran masing-masing dalam upaya meningkatkan keberhasilan peserta didik. Kemdikbud (2015) memaparkan beberapa strategi dalam menguatkan kemitraan satuan pendidikan, keluarga, dan masyarakat yaitu: Peran keluarga dalam menguatkan kemitraan antara lain meningkatkan pengetahuan dan keterampilan keluarga tentang pola asuh positif yang sesuai dengan potensi dan kebutuhan anak; ketersediaan waktu orang tua untuk mendampingi dan berinteraksi dengan anak di rumah secara cukup baik kualitas maupun kuantitasnya; ketersediaan waktu orang tua untuk terlibat dalam kegiatan sekolah sesuai dengan program yang disepakati; menciptakan lingkungan belajar di rumah yang menyenangkan dan mendorong kreativitas anak; menjalin interaksi dan komunikasi yang hangat penuh kasing sayang dengan anak; memberikan motivasi dan menanamkan rasa percaya diri pada anaknya untuk beprestasi; dan menjalin hubungan dan komunikasi yang aktif dengan sekolah untuk menciptakan lingkungan budaya belajar yang kondusif.

Peran sekolah sebagai pihak penyelenggara pendidikan harus mampu menciptakan ekosistem pendidikan yang aman, nyaman, ramah, dan sehat yang dapat menumbuhkan karakter dan budaya prestasi peserta didik melalui Manajemen Berbasis Sekolah (MBS). Sa'ad \& Sadiq (2014) memaparkan untuk menguatkan hubungan sekolah dengan masyarakat dan keluarga diperlukan pertemuan seperti lokakarya tentang pentingnya kemitraan antara sekolah, keluarga, dan masyarakat. Dijelaskan pula bahwa kepala sekolah harus berusaha maksimal untuk memiliki lebih banyak pengetahuan tentang kemitraan antara sekolah, masyarakat, dan keluarga.

Sedangkan peranan komite sekolah adalah sebagai pemberi pertimbangan, pendukung, pengontrol, dan mediator terhadap kepentingan sekolah. Peranan komite sekolah mengacu pada lima prinsip yaitu fokus pada mutu, bottom-up planning and decision making, manajemen yang transaparan, pemberdayaan masyarakat, peningkatan mutu secara berkelanjutan yaitu dengan cara mendukung kebijakan program kemitraan yang telah ditetapkan sekolah; melaksanakan kebijakan program kemitraan yang telah ditetapkan bersama dengan pihak sekolah; dan bersama dengan 
kepala sekolah dan guru mengevaluasi pelaksanaan program penguatan kemitraan satuan pendidikan, keluarga, dan masyarakat. Sa'ad \& Sadiq (2014) mengemukakan bahwa masyarakat memiliki kontribusi yang besar dalam pengembangan pendidikan dasar seperti menyediakan lahan untuk membangun sekolah, menyediakan dana, fasilitas, mengawasi kejadian yang ada di sekolah, membangun ruang kelas tambahan dan membantu dalam pemeliharaan ketidakdisiplinan.

Berdasarkan hasil wawancara, beberapa hambatan-hambatan dalam melaksanakan kemitraan di SD wilayah Kebumen meliputi: pihak sekolah belum dapat optimal dalam melaksanakan program yang telah dicanangkan karena tugas pokok yang sudah menyita waktu, tenaga, dan pikiran; kelompok paguyuban orang tua/wali masih dianggap baru sehingga tidak mudah mengaktifkan orang tua/wali ke sekolah; wali hanya terbiasa datang ke sekolah dua kali setahun pada saat mengambil rapor sehingga komunikasi wali kelas dengan orang tua masih kurang maksimal terkait dengan informasi perkembangan anak baik di rumah dan di sekolah; orang tua/wali cenderung lebih mempercayakan kepada sekolah dalam urusan pendidikan anak

\section{SIMPULAN}

Hasil analisis menunjukkan bahwa: 1) Keterlaksanaan kemitraan di SD wilayah Kebumen menunjukkan kategori Baik (B) dengan persentase 82,50\%; Kemitraan di SD wilayah Kebumen berpengaruh secara signifikan terhadap hasil belajar siswa yaitu dengan nilai signifikansi $0,000<0,05$; 3) Hambatan-hambatan dalam melaksanakan kemitraan di SD wilayah Kebumen meliputi: pihak sekolah sekolah belum dapat optimal dalam melaksanakan program yang telah dicanangkan karena tugas pokok yang sudah menyita waktu, tenaga, dan pikiran; kelompok paguyuban orang tua/wali masih dianggap baru sehingga tidak mudah mengaktifkan orang tua/wali ke sekolah; wali hanya terbiasa datang ke sekolah dua kali setahun pada saat mengambil rapor sehingga komunikasi wali kelas dengan orang tua masih kurang maksimal terkait dengan informasi perkembangan anak baik di rumah dan di sekolah; orang tua/wali cenderung lebih mempercayakan kepada sekolah dalam urusan pendidikan anak.

\section{DAFTAR PUSTAKA}

Alves, A.F, Gomes, C.M.A, Martins, A., \& Almeida, L.S. (2017). Cognitive Performance and Academic Achievement: How do Family and School Converge?. European Journal of Education and Psychology 10: 49-56.

Boonk, L., Gijselaers, H.J.M., Ritzen, H., Gruwel, S. (2018). A Review of the Relationship Between Parental Involvement Indicators and Academic Achievement. Education Research Review Vol 24: 10-30.

Decker, L.E. \& Decker, V. A. (2003). Home, School, and Community Partnership. Lanham: The Scarecrow Press, Inc.

Epstein, J.L. \& Voorhis, F.L.V. (2010). Professional School Counseling. Dalam www.schoolcounselor.org.

Hermawan \& Suryono. (2016). Partisipasi Masyarakat dalam Penyelenggaraan Program-Program Pusat Kegiatan Belajar Masyarakat Ngudi Kapinteran. Jurnal Pendidikan dan Pemberdayaan Masyarakat. Vol 3 (1): 97-108.

Kemdikbud. (2015). Petunjuk Teknis Kemitraan Keluarga, Satuan Pendidikan, dan Masyarakat di SD. Jakarta: Kemdikbud Direktorat Jenderal PAUD dan Pendidikan Masyarakat Direktorat Pembinaan Pendidikan Keluarga.

Ningrum, W.R. (2016). Pengaruh Peranan dan Pola Asuh Orang Tua Terhadap Hasil Belajar Siswa Sekolah Dasar Negeri di Kecamatan Bogor Barat. Jurnal Pendidikan. Vol 17 (2): 129-137.

Nyatuka, B.O. \& Nyakan, P.O. (2015). Home-School-Community Partnership: An Imperative in Teacher Education Programmes in Kenya. International Journal of Education and Research. Vol. 3 (11), 261-272. 
Rachman, Sc. (2015). Pentingnya Pendidikan Sekolah Dasar, https://disdik.bekasikab.go.id/berita-pentingnya-pendidikan-sekolah-dasar.html, diunduh 22 Oktober 2016.

Utari, R. (2010). Tantangan Kemitraan Orang Tua, Sekolah, dan Masyarakat. Jurnal Manajemen Pendidikan. No 02 (VI): 93-107.

Sa'ad \& Sadiq. (2014). The Relevance of School Community Relationship on the Development of Primary Education in Azare Metropolis of Bauchi State, Nigeria. Journal of Research \& Method in Education. Vol 4 (6): 23-29.

Judiani,S. (2010). Implementasi Pendidikan Karakter di Sekolah Dasar Melalui Penguatan Pelaksanaan Kurikulum. Jurnal Pendidikan dan Kebudayaan. Vol 16 (III): 280-289.

Sudjana. (2005). Metode Statistika Edisi ke-6. Bandung: Tarsito.

Arikunto,S. (2009). Manajemen Penelitian. Jakarta: Rineka Cipta.

Undang-Undang Republik Indonesia Nomor 20. (2003). Sisekolah dasariknas dan Peraturan Pemerintah Nomor 47 Tahun 2008 tentang Wajib Belajar. Bandung: Citra Umbara.

Usman, S. (2014). Meningkatkan Mutu Pendidikan Melalui Penerapan Manajemen Berbasis Sekolah. Jurnal IImiah Didakta. Vol 15 (1): 13-31. 